\title{
ТИХОЮ, НЕВТОМНОЮ ПРАЦЕЮ ЛЮБІТЬ УКРАЇНУ (до 75-річчя Всеволода Миколайовича Сеньківського)
}

У березні цього року виповнилося 75 років із дня народження завідувача кафедри комп'ютерних наук та інформаційних технологій Української академії друкарства, доктора технічних наук, професора Всеволода Миколайовича Сеньківського.

\section{Дещо з біографії професора}

Всеволод Миколайович народився на Станіславівщині (нині Івано-Франківська область) 16 березня 1943 р. У 1961-му став студентом механіко-математичного факультету Львівського державного університету ім. Івана Франка, який закінчив у 1969 р. за спеціальністю «Математика, обчислювальна математика».

Після здобуття фаху короткий час працював інженером-програмістом обчислювального центру Львівського облстатуправління. Пізніше перейшов у новостворену групу програмістів Українського науково-дослідного інституту поліграфічної промисловості. Протягом 1970-1986 рр. працював у науково-дослідному інституті: старшим науковим співробітником і керівником групи; завідувачем відділу програмування та обчислювальних методів; завідувачем лабораторії редакційно-видавничих систем; завідувачем відділу розробки автоматизованих систем переробки текстової інформації та завідувачем відділом автоматизованих систем управління.

У 1982 р. у Всесоюзному науково-дослідному інституті комплексних проблем поліграфії захистив дисертаційну роботу

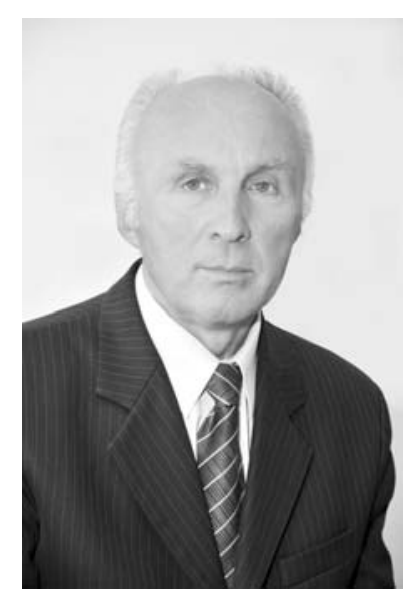

«Исследование и разработка информационного и математического обеспечения систем переработки текста книжных изданий» на здобуття наукового ступеня кандидата технічних наук. Робота була виконана під керівництвом Юрія Марковича Овчіннікова та Анатолія Васильовича Золотухіна.

3 науково-дослідного інституту Всеволод Миколайович переходить на викладацьку роботу до Українського поліграфічного інституту ім. Івана Федорова, де працював на кафедрі вищої (1986-1992), а потім прикладної математики (1992-1998).

1996 р. в Українській академії друкарства захистив дисертаційну роботу «Методологія проектування систем комп'ютерного підготування видань» на здобуття наукового ступеня доктора технічних наук.

Завідує кафедрами академії друкарства: прикладної математики (пізніше кафедра називалася - прикладної математики та комп'ютерних інформаційних

(C) $2018 \mathrm{p}$. 
систем) з 1998 до 2008-го; електронних видань (нині - кафедра комп'ютерних наук та інформаційних технологій) з 2008 р.

Професор Сеньківський автор та співавтор близько 200 наукових і навчально-методичних публікацій. Під його керівництвом захищено тринадцять дисертаційних робіт на здобуття наукового ступеня кандидата технічних наук. Всеволод Миколайович - член спеціалізованих вчених рад із захисту дисертацій (Д35.101.01 при Українській академії друкарства та Д35.052.14 при Національному університеті «Львівська політехніка») і редколегій фахових видань («Наукові записки Української академії друкарства», «Поліграфія і видавнича справа», «Комп'ютерні технології друкарства», «Квалілогія книги»); тривалий час був експертом ради з галузевого машинобудування ВАКу України.

Всеволод Миколайович приймає активну участь в атестації науково-педагогічних кадрів, зокрема він неодноразово опонував дисертації у ВПІ КПІ ім. Ігоря Сікорського.

\section{Творча лабораторія вченого}

Оскільки професор Сеньківський був активним дописувачем фахових видань Української академії друкарства, що готувалися до друку у видавництві академії, ми протягом багатьох років регулярно спілкувалися не тільки з видавничих питань, а й з багатьох інших. Тож я мав можливість спостерігати зсередини як працює його творча лабораторія.

Всеволод Миколайович ніколи не займається саморекламою: ви ніколи не почуєте від нього, що в результаті його робіт чи робіт його учнів, уперше в світі відбулося кардинальне зменшення витрат фарби в друкарському процесі за рахунок застосування певних математичних моделей чи інші моделі і маніпуляції змінили властивості води... Професор скромна людина, але дуже добре знає ціну собі й тому, що він робить.

Тим, хто не знайомий із методами роботи В. М. Сеньківського, може видатися дивним, що він завжди дуже чітко та ясно ставить технічне завдання, добре уявляючи собі яких результатів варто очікувати при розв'язанні тієї чи іншої наукової проблеми. Це знання є результатом кропіткої внутрішньої роботи професора... Всеволода Миколайовича завжди цікавила думка співрозмовника з даного питання. Тож в процесі обміну думками з іншими професор акумулював певні гіпотези, формулював завдання для себе та своїх учнів. Всеволод Миколайович цікавий співрозмовник і глибокий учений.

Останні десять років, коли В. М. Сеньківський очолює кафедру комп'ютерних наук та інформаційних технологій академії друкарства, він зміг практично з нуля організувати їі роботу з підготовки фахівців вищої кваліфікації (кандидатів наук, а тепер докторів філософії). Також за останні роки окрім підготовки бакалаврів та магістрів за традиційною для академії спеціальністю «Видавництво та поліграфія», кафедра розпочала підготовку фахівців ще 3 двох спеціальностей: «Комп'ютерні науки» та «Інформаційні системи та технології».

\section{Роки не беруть ювіляра}

Всеволод Миколайович розпочинав свою наукову діяльність з участі у розробленні першої 
в СРСР автоматизованої системи підготування до випуску книжкових видань для рядковідливних автоматів; далі була серія подібних систем, які завершилися унікальною розробкою - системою автоматичного верстання складних книжкових видань для фотоскладання. Звичайно, технологічний поступ не стояв на місці й Всеволод Миколайович переключився далі на інформаційні технології проектування процесів створення друкованих та електронних видань.

Коло зацікавлень ученого не обмежується тільки редакційно-видавничими процесами, від яких Всеволод Миколайович з учнями перейшов до розв'язання проблем друкарських та брошурувальнопалітурних процесів, створення видавничих інформаційних технологій для мобільних пристроїв й виглядає на те, що він не збирається зупинятися на досягнутому.

\section{Людина, учений, патріот}

Всеволод Миколайович уважна та чуйна людина. Життя його було непростим: війна, повоєнна розруха та смерть батька наклали свій відбиток на подальше життя майбутнього вченого. Він належав до соціально чужих елементів й це на довго позначилося на стосунках $з$ оточуючими. Випробування долі він пройшов гідно та подолав їх, довівши відомі слова Вольтера про те, що ніколи не буває великих справ без великих труднощів.

Всеволоду Миколайовичу пощастило: він може розраховувати не тільки на себе - у нього $€$ прекрасна дружина пані Уляна, що завжди підтримує його, з якою вони йдуть по життю разом; двоє дітей, зростають онуки.

Наукові здобутки Всеволода Миколайовича також вагомі: під його керівництвом сформульовано та розкрито суть методології прогностичного забезпечення якості видавничо-поліграфічних процесів та електронного видавництва на підставі використання інформаційної концепції формалізованого подання та опрацювання факторів впливу на вказані процеси за допомогою семантичних мереж, нечіткої логіки та нейронечітких мереж. Методологія проектування систем комп'ютерного підготування видань послужила основою розроблення алгоритмів та програм автоматичного (комп'ютерного) форматування книжкових видань, що знайшло своє вираження у розробленні автоматизованих систем опрацювання текстів книжкових видань, впроваджених на поліграфічних підприємствах України, Молдови, Російської Федерації, Узбекистану.

Хочеться відзначити ще одну рису Всеволода Миколайовича він справжній патріот, патріот свого навчального закладу, нашої країни. Сьогодні, коли поняття патріотизму знівельоване нашими політиками, Всеволод Миколайович продовжує свою тиху, непомітну, але від того не менш важливу невтомну кропітку працю з виховання фахівців та науковців майбутнього нашої країни. Його життя $€$ наочною ілюстрацією відомого виразу, що став крилатим: «Не потоком шумних і галасливих фраз, а тихою, невтомною працею любіть Україну». 